\title{
Regulatory Capital Planning and Deferred Tax Assets in a Post-Financial Crisis Environment
}

\author{
Evan M. Eastman ${ }^{\mathrm{a}}$ \\ Florida State University \\ Anne C. Ehinger ${ }^{\mathrm{b}}$ \\ Florida State University \\ Cathryn M. Meegan ${ }^{\mathrm{C}}$ \\ Jacksonville University
}

October 2021

\begin{abstract}
Insurance regulators substantially relaxed rules on deferred tax asset (DTA) inclusion in regulatory capital calculations during and following the financial crisis. We find evidence life insurers use additional discretion in regulation to increase the level of DTAs admitted into regulatory capital, especially when they have greater incentives to do so. As DTAs are less liquid relative to other assets, our study raises the concern that life insurance firms may appear more financially stable than the reality of their underlying economic condition. Consistent with this concern, we find firms with relatively low levels of regulatory capital admit more DTAs than can be supported by future profitability. Our study has important implications for regulators considering changes to capital standards for other financial institutions.
\end{abstract}

Keywords: Deferred Tax Assets; Regulatory Capital; Insurance; Regulation JEL Codes: G18; G22; H25; M41; M48

The authors would like to thank Mike Barth, Nikki Chappell, Russ Hamilton (discussant), Pingyi Lou (discussant), Mike Mayberry (discussant), Alyssa Moore, Jeff Paterson, Sabrina Petrosky, Spencer Pierce, Dan Schwarcz, Bridget Stomberg, Jianren Xu, Dan Yang (discussant), the Texas A\&M Tax Readings Group, conference participants at the 2020 American Taxation Association Midyear Meeting, the 2020 World Risk and Insurance Economics Congress, the 2020 American Accounting Association Annual Meeting, the 2020 Southern Risk and Insurance Association Annual Meeting, and several individuals with the National Association of Insurance Commissioners for helpful comments and discussions. We also thank Mary Kelly and MSA Research for generously sharing data on Canadian insurers.

${ }^{a}$ Dr. William T. Hold/The National Alliance Program in Risk Management/Insurance, College of Business, Florida State University, Tallahassee, FL, 32306, email: eeastman@business.fsu.edu.

b Department of Accounting, College of Business, Florida State University, Tallahassee, FL, 32306, email: aehinger@business.fsu.edu.

c Department of Accounting, Finance, and Analytics, Davis College of Business, Jacksonville University, Jacksonville, FL, 32211, email: cmeegan@ju.edu. 


\title{
Regulatory Capital Planning and Deferred Tax Assets in a Post-Financial Crisis Environment
}

\begin{abstract}
Insurance regulators substantially relaxed rules on deferred tax asset (DTA) inclusion in regulatory capital calculations during and following the financial crisis. We find evidence life insurers use additional discretion in regulation to increase the level of DTAs admitted into regulatory capital, especially when they have greater incentives to do so. As DTAs are less liquid relative to other assets, our study raises the concern that life insurance firms may appear more financially stable than the reality of their underlying economic condition. Consistent with this concern, we find firms with relatively low levels of regulatory capital admit more DTAs than can be supported by future profitability. Our study has important implications for regulators considering changes to capital standards for other financial institutions.
\end{abstract}

Keywords: Deferred Tax Assets; Regulatory Capital; Insurance; Regulation JEL Codes: G18; G22; H25; M41; M48 


\section{INTRODUCTION}

Financial institutions play a dominant role in the U.S. economy, representing 7.4 percent of gross domestic product in 2018 (U.S. Department of Commerce 2019). ${ }^{1}$ The 2007-2009 financial crisis illustrates the sensitivity of the U.S. market to financial institution insolvency (e.g., Campello, Giambona, Graham, and Harvey 2011; Cornett, McNutt, Strahan, and Tehranian 2011). As a means of preventing financial institution failures, regulators require these firms to maintain a minimum amount of regulatory capital. The purpose of regulatory capital calculations is to determine if financial institutions have sufficient capital, given their size and risk profile, to support business operations (NAIC 2020). ${ }^{2}$ The calculation generally allows for inclusion of a portion of deferred tax assets (DTAs) as regulatory capital, leading to debates on how much of a firm's DTAs are sufficiently convertible to capital to meet this requirement. ${ }^{3}$ Following the financial crisis, state insurance regulators in the U.S. updated standards increasing the amount of DTAs includable in regulatory capital as a means of regulatory forbearance. We use the changes in regulation in the U.S. insurance industry to provide evidence on how changes in regulation affect regulatory capital and examine potential consequences of allowing more discretion for inclusion of deferred tax assets in regulatory capital.

In this paper, we examine three broad research questions. First, we test whether life insurers increase the amount of admitted DTAs in regulatory capital following the adoption of SSAP 10R and SSAP 101—regulatory changes to statutory accounting standards that allow for greater

\footnotetext{
${ }^{1}$ Banks represent 3.1 percent while insurance companies represent 2.8 percent of gross domestic product.

${ }^{2}$ In general, financial institutions report two categories of assets. The first category represents assets that are generally more readily convertible to cash and, therefore, can be counted for regulatory capital purposes. The insurance industry refers to these assets as "admissible" or "admitted" assets. The second category represents non-liquid assets, which are not counted for regulatory capital purposes. The insurance industry refers to these assets as "non-admissible" or "non-admitted" assets.

${ }^{3}$ Unless otherwise indicated, DTAs refer to net deferred tax assets, which are adjusted gross deferred tax assets (deferred tax assets less the valuation allowance) less deferred tax liabilities.
} 
inclusion of DTAs in regulatory capital. ${ }^{4}$ Second, we examine whether firms with greater incentives to increase regulatory capital include a greater proportion of overall DTAs in regulatory capital. Finally, we examine if firms include DTAs that are unlikely to be realized (and, therefore, are not easily convertible to usable capital) within the mandated time period required for inclusion as admitted DTAs, thereby suggesting that insurers are strategically increasing capital through DTA admissibility.

This topic is of interest not only to researchers, but also to regulators and consumers. From a regulatory perspective, our findings have clear implications for developing capital requirements for financial institutions. Researchers have called for additional evidence on firm behavior in response to regulation, specifically with respect to the subjectivity surrounding including DTAs in regulatory capital (Hanlon and Heitzman 2010; Acharya and Ryan 2016). Skinner (2008), for example, finds that Japan's concurrent adoption of deferred tax accounting for financial reporting and allowance of DTAs in regulatory capital afforded banks discretion in their regulatory capital calculations and contributed to the Japanese financial crisis. Gallemore (2012) examines consequences of including DTAs in regulatory capital during the financial crisis and finds empirical evidence that banks with a higher proportion of capital composed of DTAs prior to the financial crisis were more likely to fail during the recession. Our setting differs from these papers in important ways. First, unlike Gallemore (2012), we examine a change in regulatory capital regulation. Second, unlike Skinner (2008), the change in regulatory capital regulation does not coincide with a change in financial reporting regulation. These two differences afford us sharper identification of the consequences of including DTAs in regulatory capital. To our knowledge, our

\footnotetext{
${ }^{4}$ An "SSAP" is a Statement of Statutory Accounting Principles. These are the rules that govern insurer regulatory financial reporting (i.e., statutory accounting principles or SAP).
} 
paper is the first to examine consequences of a change in regulatory capital regulation with respect to DTAs in isolation.

Our findings are also of interest to consumers. Due to inherent information asymmetry between consumers and financial institutions, regulators are tasked with ensuring that financial institutions maintain a minimum level of financial strength so that they can fulfill future obligations (Munch and Smallwood 1981; Bhattacharya, Boot, and Thakor 1998; Klein 2012). Financial institutions exercising discretion over DTAs may appear better able to meet their obligations than supported by the underlying tax positions creating the DTAs, thereby providing an inaccurate depiction of their financial strength to regulators and consumers. The costs of insolvencies are potentially passed on, at least in part, to policyholders. For example, Barrese and Nelson $(1994,15)$ estimate that around 21 percent of insolvency costs are passed on to consumers. Additionally, even if financial institutions do not actually become insolvent, increased risk can affect prices. Specifically, prior research finds evidence that consumers of financial products are risk-sensitive in that they demand lower prices when insolvency risk is higher (Flannery and Sorescu 1996; Sommer 1996; Park and Peristiani 1998; Epermanis and Harrington 2006). However, if consumers cannot untangle the increased risk associated with less solvent assets (such as DTAs) included in regulatory capital, firms may appear to be financially stronger than their actual economic condition, translating into higher prices for consumers. Therefore, any finding that relates DTAs to increased firm risk has potential implications for consumers through prices.

Using ordinary least squares, we first regress the ratio of admitted DTAs to total DTAs on indicators for the various statutory accounting rules determining how life insurers must account 
for DTAs, as well as other hypothesized determinants of DTAs. ${ }^{5}$ By doing so, we discern whether and to what extent the inclusion of DTAs in regulatory capital has increased over time. We find evidence that the total dollar amount of admitted DTAs has been increasing over time in the life insurance industry, but we do not find a corresponding increase in total (admitted plus nonadmitted) DTAs. This result suggests that life insurers are using the discretion afforded in new regulation to increase the level of admitted DTAs.

Second, we test whether firms with relatively low levels of regulatory capital use discretion over DTAs to boost their capital in an effort to avoid regulatory scrutiny by state insurance regulators. We find evidence that life insurers with relatively low levels of regulatory capital (i.e. low risk-based capital ratios (RBC)) tend to include lower levels of DTAs in regulatory capital prior to regulatory updates but include incrementally more DTAs following increased leniency permitted by SSAP 10R and SSAP 101. Specifically, we find evidence that insurers with low RBC ratios admit 11 to 14 percent more DTAs following the implementation of these regulatory updates.

Finally, we examine if firms with greater incentives to increase regulatory capital include DTAs that are unlikely to be realized within the mandated time period for inclusion in total regulatory capital. DTAs generally require future profitability to be realized and used to meet company obligations. We find that, in general, DTAs are positively associated with future profitability, suggesting the average life insurer includes DTAs it expects to realize within the near future, as outlined by the regulation. However, we find a negative association between admitted DTAs and future pretax ROA in years $t+2$ and $t+3$ for firms with low RBC ratios. This result

\footnotetext{
${ }^{5}$ Consistent with insurer regulatory capital calculations, we use net DTAs in our analyses. The calculation consists of reducing any DTAs admitted into regulatory capital by any DTLs that could offset these DTAs in the applicable time period. See Section II for additional details.
} 
suggests that these firms with incentives to increase regulatory capital may be manipulating their RBC ratios by including DTAs in regulatory capital that they most likely will not be able to realize. In our main tests, we limit our sample to profitable firms to remove the effect of net operating loss carryovers on the level of total DTAs reported and the effect of future losses on a firm's ability to realize admitted DTAs. In an alternative specification, we find our results are robust to excluding financial crisis years, further isolating the effect of the use of discretion allowed by the new regulations.

We make several contributions to the literature. First, we contribute to the literature on regulation, managerial incentives, and accounting discretion. In general, Petroni (1992) finds that insurers exercise discretion over loss reserves to appear financially stronger. Gaver and Paterson (1999) find that this discretion weakens following a change in regulation introducing risk-based capital requirements. Hanley, Jagolinzer, and Nikolova (2018) find that financially weaker insurance companies inflate their fair value estimates to produce regulatory capital ratios that appear financially healthier. Beatty, Chamberlain, and Magliolo (1995) find that banks exercise discretion over loan charge-offs, loan loss provisions, and the decision to issue securities as a means of managing their regulatory capital ratios. We identify a new area of discretion available to a sub-sample of financial institutions in the U.S.-inclusion of DTAs in the risk-based regulatory capital ratio for life insurers—and examine managerial discretion over inclusion in response to evolving regulation.

Second, we specifically contribute to the literature examining how financial institutions react to regulatory changes. Koijen and Yogo (2016) find that insurers respond to changing reserving requirements by using more captive reinsurance ("shadow insurance”). Eastman, Eckles, and Van Buskirk (2021) find evidence consistent with insurers overstating claims estimates 
following the implementation of minimum medical loss ratio requirements with the Affordable Care Act. Murray and Nikolova (2021) find that insurer demand for assets substantially changed following the implementation of risk-based capital requirements in the early 1990s. Becker, Opp, and Saidi (2021) and Hanley and Nikolova (2021) find that insurers are more likely to hold on to downgraded securities if they do not have to account for these securities in their regulatory capital calculations. Another string of studies in this area examines insurer behavior following shocks to regulatory capital, specifically focusing on risk-taking incentives (e.g., Ellul, Jotikasthira, and Lundblad 2011; Ellul, Jotikasthira, Lundblad, and Wang 2015). Examining how firms respond to regulatory changes provides a stronger research setting compared to static regulatory environments. Additionally, this is an important research area for regulators as they continue to adjust and implement regulations to better monitor the financial sector.

Third, we contribute to the literature examining manager discretion over tax accounts. Prior literature finds evidence consistent with managers using tax accounts to engage in earnings management. Dhaliwal, Gleason, and Mills (2004) find evidence suggesting that managers manipulate their fourth quarter effective tax rate downward to meet earnings benchmarks. Other research finds that managers use discretion in the designation of permanently reinvested earnings (Krull 2004) and the tax cushion (Gupta, Laux, and Lynch 2016) to meet earnings targets. With respect to DTAs, there is mixed evidence on whether managers use deferred taxes to meet earnings targets (Miller and Skinner 1998; Bauman, Bauman, and Halsey 2001; Schrand and Wong 2003; Frank and Rego 2006). However, to the best of our knowledge, little research exists examining manager discretion over tax accounts to meet regulatory capital requirements. With respect to DTAs, Skinner (2008) finds that managerial incentives during the Japanese financial crisis led firms to use discretion over the inclusion of DTAs in regulatory capital following adoption of 
deferred tax accounting for financial reporting purposes, and this discretion allowed them to achieve their regulatory capital goals. In our setting, the life insurance industry, we are able to examine responses to changes in regulation separately from responses to changes in accounting standards. Our research answers Hanlon and Heitzman's (2010, 133-134) call for additional research on financial institutions' responses to regulation allowing for greater inclusion of tax accounts in regulatory capital.

Finally, our research contributes to the literature examining the role of regulation in maintaining stability and solvency in the financial industry, especially following the financial crisis of 2007-2009 (Billio, Getmansky, Lo, and Pelizzon 2012; Koijen and Yogo 2015; Acharya and Ryan 2016). Financial regulation generally uses regulatory capital ratios as a means of determining the stability and solvency of these firms, thus incentivizing management to use all means available to maintain and improve these ratios. We find that managers use discretion in the regulations with respect to including DTAs in regulatory capital, and as discretion in the regulation increases, so does the level of admitted DTAs. We also find that firms with greater incentives to increase their regulatory capital ratios appear to use the additional discretion in DTA regulation to do so. These admitted DTAs increase firm risk when future profitability does not support realization of these DTAs, thus increasing insurers' risk of being unable to pay future claims. This increased risk raises similar concerns as those thought to have precipitated the most recent financial crisis.

\section{BACKGROUND}

\section{Deferred Tax Asset Accounting}

SFAS 109 (codified as ASC 740), effective for fiscal years beginning after December 15, 1992, requires firms to use an asset and liability approach for reporting income taxes (Financial 
Accounting Standards Board 1992; 2009). Firms report estimated future tax effects related to temporary book-tax differences and carryforwards as deferred tax assets (DTAs) or liabilities (DTLs) on the balance sheet. ${ }^{6}$ A gross DTA represents a future tax benefit, either as a reduction in income taxes payable or a refund of previous income taxes paid. In order to use the gross DTA, a firm must have sufficient future income of the appropriate type and in the appropriate jurisdiction. If an evaluation of all evidence, positive and negative, suggests it is more likely than not that the future income will not be realized and the gross DTA will not be used, firms must accrue a valuation allowance against the gross DTA. Therefore, adjusted gross DTAs (deferred tax assets less valuation allowance) should represent the future tax benefits that management believes it more likely than not they will utilize.

The accrual of DTAs and the valuation allowance requires managers to exercise discretion (Miller and Skinner 1998; Visvanathan 1998). There is some concern with regulators and the public that managers may use this discretion opportunistically to meet particular targets. Research conducted soon after the passage of SFAS 109 finds mixed results with respect to the use of the valuation allowance for earnings management. Several studies find little evidence of earnings management to meet prior earnings or to take a big bath (Frank and Rego 2006). Others suggest that the valuation allowance is based on expectations of future performance, consistent with the requirements of SFAS 109, and is predictive of future income and cash flows (Miller and Skinner 1998; Jung and Pulliam 2006; Christensen, Paik, and Stice 2008; Dhaliwal, Kaplan, Laux, and Weisbrod 2013). In contrast, some studies find possible opportunistic use of the valuation

\footnotetext{
${ }^{6}$ Under the tax law in effect during our sample period, current year net operating losses could be carried back three years for life insurers for a tax refund. The carryback period was extended to five years for both 2008 and 2009. Net operating losses not carried back are carried forward and create DTAs that require future taxable profits to use the tax benefits created.
} 
allowance to smooth earnings (Schrand and Wong 2003) or meet analysts' forecasts (Bauman et al. 2001; Frank and Rego 2006).

The U.S. life insurance industry provides a powerful setting in which to examine the issue of manager discretion over deferred taxes and regulatory capital. First, we have detailed adjusted gross DTA and DTL data from statutory annual reports required for U.S. insurers, allowing us to observe the amount of DTAs that insurance firms classify as admitted assets for regulatory purposes. In addition, Schipper (1989) suggests focusing studies of opportunistic management of accounting figures on situations with clear incentives. One such incentive occurs for financial institutions that have sufficiently low levels of regulatory capital and are at risk of violating their regulatory capital requirements. Visvanathan (1998) finds evidence suggesting that firms in financial distress may be more likely to engage in earnings management using the valuation allowance. Managers also have incentives to engage in opportunistic activities when new regulation allows them to do so. With respect to the banking industry, Schrand and Wong (2003) find, in general, that managers do not use the valuation allowance to manage earnings, but firms with sufficient regulatory capital reserve greater valuation allowances at adoption and use these valuation allowances to smooth future earnings. To our knowledge, no study has focused on the use of DTAs to manage regulatory capital in the U.S. insurance industry. For insurance companies, there are two separate situations where managers may exercise discretion over DTAs: in calculating the original accrual of DTAs and related valuation allowance and in calculating the amounts included for regulatory purposes using tax planning. Following the financial crisis, the insurance industry experienced two regulatory changes over time that have increased insurer discretion over DTA reporting, thus allowing us to examine the effect of increased discretion over DTA reporting on financial institution regulatory capital ratios. 


\section{Institutional Background-The U.S. Life Insurance Industry \\ Insurance Regulation and Statutory Accounting}

The insurance industry in the U.S. is largely regulated by individual states. The McCarranFerguson Act, passed in 1945, establishes that individual states can each govern and regulate their own insurance market. In an effort to harmonize regulation across states, the insurance commissioners from every state are part of a non-profit corporation known as the National Association of Insurance Commissioners (NAIC). While the NAIC is not a government bodyand, therefore, has no official legislative authority—-the organization is "the most important and powerful entity in insurance regulation” (Schwarcz 2018, 193).

While certain regulations vary substantially from state to state, such as rate regulation (i.e., the regulation of insurance pricing), the NAIC has achieved substantial homogeneity for solvency regulation. Following a wave of serious insolvencies in the late 1980s and early 1990s, federal regulators threatened to nationalize insurance regulation. The NAIC responded, in part, by creating the Financial Standards and Accreditation Program. In order to be a part of this program, a state insurance department must comply with the NAIC’s solvency-associated model laws. ${ }^{7}$ Failing to comply with the program would result in insurance regulators being unable to defer insurance regulation to an insurer's state of domicile, which would likely result in insurers shifting operations out of the non-complying state (Schwarcz 2018). Every state is, therefore, enrolled in the Financial Standards and Accreditation Program.

\footnotetext{
${ }^{7}$ Model laws are pieces of legislation that are written by the NAIC and are intended to be passed individually by states in an effort to improve the consistency of insurance regulation across states.
} 
Insurance regulators have several methods for monitoring solvency. ${ }^{8}$ While regulators historically relied on an "early warning system" which consists of a set of ratios (e.g., Petroni 1992; Gaver and Paterson 1999), following the aforementioned series of insolvencies in the late 1980s and early 1990s, the NAIC developed and adopted a system of risk-based capital (RBC) requirements that went into effect for life insurers in $1992 .{ }^{9}$ The goal of the RBC system is to identify potentially distressed insurers before they are insolvent. Regulators achieve this by constructing an RBC ratio, which scales an insurer's adjusted capital and surplus (roughly equivalent to assets minus liabilities) by a capital calculation adjusted for the riskiness of the insurer's assets. Specifically, firms calculate their risk-based capital (RBC) ratio using the following equation:

$$
\text { RBC Ratio }=\frac{\text { Total Adjusted Capital }}{\text { Total Risk }- \text { Based Capital }}
$$

where Total Adjusted Capital is an insurer's adjusted capital and surplus. ${ }^{10}$ A firm's level of admitted DTAs represents the amount of a firm's total DTAs that are included in Total Adjusted Capital. Holding all else equal, as the amount of admitted DTAs increases, the RBC ratio also increases. Total Risk-Based Capital is intended to measure the amount of capital an insurer should hold based on how much risk it is taking. Life insurer risks are broken into four categories: asset risk, insurance risk, interest rate risk, and miscellaneous business risk. Within each of these risk

\footnotetext{
${ }^{8}$ Klein (2012) argues that insurance solvency regulation is necessary due to information asymmetry between insurance sellers and buyers-it is relatively difficult for consumers to assess the financial condition of insurers. It is also difficult for policyholders to monitor insurance sellers after the sale of the policy to ensure that they do not take excessive risk. ${ }^{9}$ The insurance industry uses the term "risk-based capital" to refer to insurance-specific regulatory capital requirements. In this paper, we use "regulatory capital" and "risk-based capital" interchangeably.

${ }^{10}$ The starting point for an insurance firm's total adjusted capital is equal to the firm's total assets minus total liabilities. There are several adjustments required to balance sheet capital and surplus for the purposes of calculating the RBC ratio. One example is that life insurers must include the asset valuation reserve (AVR), which is a liability, into adjusted capital, thus increasing the numerator of the RBC ratio.
} 
categories, the NAIC assigns RBC factors to activities according to how risky each activity is. ${ }^{11}$ For example, investing in highly rated corporate bonds carries a relatively low risk factor, while investing in common stocks carries a higher risk factor. Taking the weighted sums of the risks in each category (and then performing a covariance adjustment) results in a firm’s total RBC (i.e., the denominator of the RBC ratio in equation (1)).

Based on this ratio, firms are subject to varying levels of regulatory action once their RBC ratio falls below a certain threshold (i.e., they are not holding sufficient capital to offset the risks they are taking). Specifically, once ratios fall below 200 percent (the Company Action Level or CAL), regulators have the right to seize a company and can force the company to take action to ensure solvency in a process known as receivership (Grace, Klein, and Phillips 2003). At this point, regulators can decide whether to attempt to rehabilitate the firm, with the ultimate goal of returning it to private ownership, or, if the financial situation is too severe, liquidate the firm to reduce the impact on the firm's policyholders.

In practice, insurance regulators are under no obligation to wait until a firm’s risk-based capital ratio deteriorates before intervening. In order to prevent a firm's financial condition from declining so far that it cannot be recovered, regulators will often step in to take corrective action prior to an RBC ratio reaching 300\%. Insurers are, therefore, incentivized to maintain a sufficiently high RBC ratio — above the minimum — to avoid regulatory attention. Even aside from regulators, insurers may realize benefits from other external parties, such as investors or ratings agencies, by maintaining a sufficiently high RBC ratio. As noted in Hanley et al. (2018), ratings agencies, such as Moody’s, view regulatory capital as a strong indicator of an insurer's financial health.

\footnotetext{
${ }^{11}$ While firms disclose their total risk-based capital, they do not disclose the supporting calculation and risk-weighting assigned to each activity and asset class. Specifically, the only area of insurer statutory statements where risk-based capital is reported is in the "Five-Year Historical Data" page where total adjusted capital and risk-based capital are reported separately on lines 30 and 31, respectively (using life insurer 2016 statement instructions).
} 
Therefore, insurers that have sufficient capital to avoid regulatory scrutiny may still increase their RBC ratios to appear financially healthier to ratings agencies and investors.

Firms do not disclose the details behind their calculation of the RBC ratio (including the weighting assigned to each account based on its individual risk). However, they do disclose the unweighted amounts of admitted DTAs for purposes of calculating the RBC ratio. We scale our account of interest (i.e., the amount of admitted DTAs disclosed by the firm) by the firm's total DTAs. This variable reflects the extent to which an insurer includes admitted DTAs in its regulatory capital calculation and controls for different levels of total DTAs across insurers.

\section{DTAs in the Insurance Industry—SSAP 10, SSAP 10R, and SSAP 101}

In general, solvency regulation focuses on measuring how much of an insurance company's assets could readily be converted to cash if the company faced insolvency concerns. The amount of DTAs included in an insurer's adjusted capital and surplus (admitted DTAs) makes up a sizeable portion of these assets considered in determining a company's total adjusted capital. ${ }^{12}$ Since the financial crisis, admitted DTAs as a share of total DTAs have consistently increased for life insurers (Figure 1). The total dollar amount of admitted DTAs has increased from $\$ 15$ billion in 2007 to $\$ 33$ billion in 2016 (Figure 2).

[Insert Figures 1 and 2 here]

Since DTAs rely on future taxable income to be realized, regulation generally limits the admissibility of DTAs in regulatory capital. Historically, insurance regulators have either not allowed DTAs to be used for regulatory purposes (prior to 2001) or have allowed relatively little discretion over their admittance (beginning in 2001). However, recently the NAIC has revised the regulations guiding the amount of DTAs includable in insurance companies' total adjusted capital

\footnotetext{
${ }^{12}$ In our sample of life insurers, admitted DTAs make up approximately 4.1 percent of total regulatory capital (i.e., surplus).
} 
calculation, or insurance companies' admitted DTAs. In general, the regulations have allowed for increased inclusion over time.

For annual periods from 2001 through 2008, insurance companies were required to follow the Statement of Statutory Accounting Principles No. 10 (SSAP 10) when determining the level of admitted DTAs for regulatory capital purposes. SSAP 10 provides the strictest criteria for calculating a firm's level of admitted DTAs during our sample period. First, firms may admit any portion of gross DTAs reversing by the end of the subsequent calendar year that will result in net operating losses (NOLs) to the extent that the NOLs may immediately be carried back to prior tax returns to offset previously reported taxable income and result in an additional tax refund to the company. ${ }^{13}$ Second, with respect to remaining DTAs, firms may admit the lesser of gross DTAs that they expect to realize within one year of the balance sheet date or gross DTAs equal to 10 percent of statutory capital and surplus. Finally, a firm may admit any remaining gross DTAs if they can be used to offset existing deferred tax liabilities (DTLs). Therefore, the final DTA amount admitted into regulatory capital considers admissible gross DTAs offset by any applicable DTLs.

During the financial crisis, insurance companies pushed regulators for revisions to the admissibility of DTAs in the regulatory capital calculation. Regulators in several states began allowing insurance firms to admit more DTAs to improve their capital positions as a means of regulatory forbearance (GAO 2013) ${ }^{14}$ Life insurance companies hit hardest during the financial

\footnotetext{
${ }^{13}$ It is important to note that this portion of the regulation is forward-looking. If a firm expects DTAs in year $t+1$ to reverse and create a NOL and the firm has positive taxable income in either the current or previous tax years to absorb this future NOL, the firm includes these DTAs in regulatory capital. To the extent that the firm carries back current NOLs to recover prior income taxes paid, this amount would be reflected in income taxes payable/receivable and not in DTAs.

${ }^{14}$ Because insurers are regulated at the state level, state insurance regulators have some leeway to deviate from statutory accounting practices, either for the entire state (prescribed practices) or on an individual company basis (permitted practices). Requests for these changes increased substantially as the financial crisis worsened in 2008, with more than half of the 119 requests relating to admitting more DTAs (GAO 2013). We attribute the increase in admitted DTAs in 2008 (the year before SSAP 10R) to these discretionary allowances of increased admitted DTAs.
} 
crisis led the push for a revision of SSAP 10 in the insurance industry. ${ }^{15}$ As of 2008, life insurers had \$64 billion in unrealized losses and other-than-temporary impairments of \$60 billion (GAO 2013; Khan, Ryan, and Varma 2019). Expanding admissibility of DTAs in regulatory capital would allow life insurers to include DTAs relating to impairments taken on these assets, thus elevating their $\mathrm{RBC}$ ratios and offsetting some of the decrease in $\mathrm{RBC}$ ratios relating to an increase in risk-weighting for many insurer investments that were downgraded during the financial crisis. In 2008, the American Council of Life Insurers (ACLI) proposed several changes to regulation with the goal of providing life insurers with capital flexibility needed to operate in a highly volatile economic climate (Society of Actuaries 2009). One of the proposed changes centered around relaxing the admissibility rules for DTAs under SSAP 10. The ACLI proposed that the period for realizing DTAs be extended from one to five years and the limit as a percent of statutory capital and surplus be increased from 10 percent to 25 percent. In response, on December 7, 2009 the NAIC issued SSAP 10R, a temporary replacement of SSAP 10 effective for interim and annual periods of 2009, 2010, and 2011. SSAP 10R provided more immediate DTA admission relief to insurance companies as a means of regulatory forbearance following the financial crisis while the NAIC continued to work on new, permanent regulation. The ACLI stated that these changes would provide insurers with greater access to capital and credit necessary for serving current and future policyholders (Society of Actuaries 2010). As a result, admitted DTAs as a percent of capital for life insurers increased from over four percent in 2006 to nine percent in 2011 (GAO 2013).

\footnotetext{
${ }^{15}$ In 2009, the Clearing House Association L.L.C. and the American Bankers Association pushed for similar revisions in the banking industry and failed (American Bankers Association 2009). In October 2013, the Federal Reserve published final Basel III regulations effective January 1, 2015. These regulations limit the amount of DTAs includable in parts of the regulatory capital calculation and increase the complexity associated with DTA inclusions in other parts of the regulatory capital calculation. It is initially unclear whether these regulations will allow for increased or decreased inclusion of DTAs in regulatory capital for banks.
} 
Similar to SSAP 10, the temporary SSAP 10R has three primary categories of admissible DTAs. First, insurance companies now admit any adjusted gross DTAs (gross deferred tax assets less the valuation allowance) relating to NOLs that will be realized within one year in the form of tax refunds. While this first category largely follows SSAP 10, regulators updated the calculation of admissible DTAs to explicitly limit inclusion for firms with valuation allowances in place. Second, firms may admit any remaining adjusted gross DTAs to a greater extent. If the life insurer's RBC ratio is greater than 250 percent, admissible adjusted gross DTAs now include the lesser of any adjusted gross DTAs expected to be realized within three years or 15 percent of statutory capital and surplus. As noted in guidance issued by PwC, if adjusted gross DTAs are not expected to naturally reverse over this time period, the firm may be able to engage in tax planning strategies that would support increased reversals and admissibility (PwC 2012). As a result, the expanded horizon for estimating adjusted gross DTA realization allows management additional opportunities to exercise discretion over identifying potential future tax planning strategies allowing for current admission in regulatory capital. Third, with respect to any remaining adjusted gross DTAs that may be used to offset DTLs, companies now also have to consider the character of remaining adjusted gross DTAs and DTLs. More specifically, firms may only use ordinary adjusted gross DTAs to offset ordinary DTLs and capital adjusted gross DTAs to offset capital DTLs.

Effective January 1, 2012, SSAP 101 replaced SSAP 10 and SSAP 10R as guidance for the admission of DTAs into regulatory capital. SSAP 101 largely follows SSAP 10R, with one notable exception. Firms still start by considering adjusted gross DTAs relating to NOLs that can be realized as future tax refunds, and they still end by considering remaining adjusted gross DTAs that can be used to offset DTLs of similar character. However, SSAP 101 modifies the second step 
by providing additional guidance on admission based on RBC ratios. If the company's RBC ratio is greater than 300 percent, the company may admit the lesser of adjusted gross DTAs expected to be realized over three years or 15 percent of statutory capital and surplus. If the company's RBC ratio is between 200 and 300 percent, the company may admit the lesser of adjusted gross DTAs expected to be realized over one year or 10 percent of statutory capital and surplus. Finally, if the company's RBC ratio is below 200 percent, the company admits zero additional adjusted gross DTAs in regulatory capital. ${ }^{16}$ See Table 1 for a summary of regulatory changes as they relate to the life insurance industry.

\section{[Insert Table 1 here]}

One aspect of all three regulations that we wish to highlight is that they attempt to minimize a severely distressed firm's ability to inflate its DTAs. However, even firms with relatively low levels of risk-based capital have an incentive and ability to inflate admitted DTAs. First, firms may have RBC ratios above 300 percent and still be financially distressed. ${ }^{17}$ Managers at these firms have incentives to use discretion in the regulations to include DTAs to a greater extent in order to appear more financially stable. Second, state insurance regulators are not legally required to wait until an insurer has triggered the minimum RBC ratio requirements before intervening. It is common for firms to be placed under informal solvency screening prior to any formal action (e.g., Leverty and Grace 2012, 764), suggesting that insurers have incentives to boost their reported RBC ratios even if they are above minimum standards. Taken together, even with regulation stipulating that firms with the lowest levels of risk-based capital are limited in the degree to which they can

\footnotetext{
${ }^{16}$ Financial institutions go to great lengths to avoid regulatory attention (e.g., Hanley et al. 2018). In general, insurance companies avoid falling below the 200 percent CAL. As a result, almost no companies in our sample approach the 300 percent risk-based capital limitation under the new regulation.

${ }^{17}$ Grace, Harrington and Klein $(1998,214)$ note that "fewer than half of the insurers that later failed had an RBC ratio below the threshold level needed to avoid increased regulatory scrutiny."
} 
admit DTAs, we still expect firms near these low levels to be incentivized to increase DTAs for regulatory capital purposes.

\section{HYPOTHESIS DEVELOPMENT}

The new regulations for the insurance industry enhance firms' ability to use tax planning to increase assets included in regulatory capital and increase distance from risk-based capital limits that would trigger regulatory action. Therefore, the insurance industry provides an ideal setting to examine the opportunistic use of this tax account where incentives are clear. In this study we test three hypotheses. First, we examine the association between the passage of SSAP 10R and SSAP 101 and life insurers' inclusion of DTAs in their regulatory capital calculation. Given the increase in the amount of discretion firms have over the level of admitted DTAs, we predict that life insurers will increase the level of admitted DTAs included in total adjusted capital. We formally propose the following hypotheses in alternative form:

H1a: The level of admitted deferred tax assets will increase following implementation of SSAP $10 R$.

H1b: The level of admitted deferred tax assets will increase following implementation of SSAP 101.

As described above, both SSAP 10R and SSAP 101 substantially increase the amount of discretion firms have over the level of admitted DTAs, primarily by extending the time period of realization. Prior studies find evidence that when facing potential regulatory scrutiny, financial institutions use their discretion over non-DTA accounts to circumvent solvency regulation (Petroni 1992; Beatty et al. 1995; Collins, Shackelford, and Wahlen 1995; Gaver and Paterson 1999; Hanley et al. 2018). Consistent with prior literature, we predict that firms with greater incentives to use discretion to manage RBC ratios and, therefore, avoid regulatory scrutiny will do so. 
H2: The level of admitted deferred tax assets will be greater for firms with lower RBC ratios relative to other firms.

While some components of DTAs are recognized more immediately in that they result in current reductions in tax payments, others depend on future taxable income in order to be realized and used to fulfill policyholder obligations through reduced future cash tax payments. Sufficiently distressed firms with lower likelihood of future profitability will most likely not fully realize the future benefits associated with many DTAs. While the ACLI pushed for the expanded inclusion of DTAs in regulatory capital to provide greater access to capital and credit for insurers, expanding the time period for inclusion under SSAP 10R and SSAP 101 also increases the likelihood that those DTAs used to gain greater access to capital and credit will go unrealized, potentially increasing the overall riskiness of the firm. Additionally, the Society of Actuaries notes that the expanded period for admitting DTAs in regulatory capital "could produce potential volatility in results and may reduce comparability within the industry” (2009, 29). As noted by Gallemore (2012, 12), unlike other components of regulatory capital, DTAs are dependent upon future taxable income and cannot be used to fulfill financial obligations in periods where a firm reports a loss. Reilly (2009, para. 21) goes so far as to refer to DTAs as “airy asset[s].” Skinner (2008) finds that banks were overly optimistic in forecasting future firm performance and the level of DTAs included in risk-based capital was not supported by future profitability, particularly for banks with the weakest capital positions. Therefore, our third hypothesis examines the association between an insurer's level of admitted deferred tax assets and future firm profitability. More specifically, we predict that if firms admit DTAs into regulatory capital consistent with expectations of future firm performance, their level of admitted DTAs should be positively associated with future firm profitability. However, if firms manipulate their capital ratios to include DTAs in regulatory capital that they do not expect to realize, the level of admitted DTAs should be negatively associated with 
future firm profitability. Given that we expect firms with lower RBC ratios to include a greater level of DTAs in regulatory capital as compared to other firms, we also expect that firms with lower RBC ratios and higher levels of admitted DTAs will have incrementally lower levels of future firm profitability. Stated formally:

H3a: The level of admitted deferred tax assets is not associated with future firm performance.

H3b: The association between a firm's level of admitted deferred tax assets and future profitability does not significantly differ between firms with lower RBC ratios and other firms.

\section{RESEARCH DESIGN}

\section{Data}

We use data from life insurers' annual statutory filings provided by the NAIC. These filings include, but are not limited to, balance sheet, income statement, regulatory capital, and tax footnote data. Our original sample includes all life insurers with financial statements from 2001 to 2016. Table 2 provides information on our sample selection process. We begin our sample in 2003. Since SSAP 10 became effective January 1, 2001, we use data from 2001 and 2002 to create lagged variables used in our regression analyses. We end our sample period in 2016 to avoid contamination from the 2017 passage of the Tax Cuts and Jobs Act.

\section{[Insert Table 2 here]}

We clean our sample by excluding observations with missing or non-positive values of assets or surplus. We also limit our sample to firms that are profitable during our entire sample period. We do so primarily to remove firms that would be more likely to record a valuation allowance at some point during the analysis. The treatment of the valuation allowance in calculating admitted DTAs changed between SSAP 10 and SSAP 10R, potentially affecting our 
ability to draw inferences on the effect of changes in regulation on firms' discretionary inclusion of DTAs in regulatory capital. Firms with valuation allowances generally also have net operating losses, resulting in the possibility that a substantial amount of DTAs relate to net operating losses, which would provide an alternative explanation for increases in the inclusion of DTAs in regulatory capital, particularly around the passage of SSAP 10R, which closely followed the financial crisis. Additionally, firms required to record valuation allowances are also more likely to be under increased scrutiny from regulators and auditors and less likely to have the opportunity to include DTAs in excess of future realizability. Finally, we exclude firms with missing or insufficient data to calculate our control variables. Our life insurer sample consists of 2,505 firmyear observations and 300 unique firms. ${ }^{18,19}$

\section{Determinants of DTAs}

In order to examine if the level of admitted DTAs increases under SSAP 10R and SSAP 101 (H1a and H1b), we estimate the following model using OLS:

$$
D T A_{i t}=\beta S S A P 10 R_{t}+\gamma S S A P 101_{t}+\phi \boldsymbol{X}_{i t}+\boldsymbol{I}_{s}+\epsilon_{i t}
$$

where DTAit is firm i's admitted net deferred tax assets in year $t$ scaled by total net deferred tax assets. A firm's admitted net deferred tax assets include a reduction for existing deferred tax liabilities that would be realized during the period under consideration. ${ }^{20} S S A P 10 R_{t}$ and $S S A P 101_{t}$ are binary variables equal to one during years when SSAP 10R and SSAP 101 were enforced, respectively, and zero otherwise. If firms increase their level of admitted DTAs following SSAP

\footnotetext{
${ }^{18}$ Due to the state-based regulatory structure of the U.S. insurance industry, insurers are commonly organized into groups with numerous affiliates operating in different states (Petroni and Shackelford 1995). For example, the Metropolitan Group consists of separate affiliates, including Metropolitan Life Insurance Co, New England Life Insurance Co, American Life Insurance Co, and Omega Reinsurance Corp, all acting under a common ownership structure. Our sample of 300 life insurers represents unique underlying affiliates of insurance groups.

${ }^{19}$ State insurance regulators enforce regulatory capital requirements at the affiliate level. Likewise, the affiliate is responsible for reporting DTAs.

${ }^{20}$ A firm reporting a net DTL has zero admitted DTAs, thus resulting in $D T A_{i t}$ equaling zero for these observations.
} 
10R and SSAP 101, we expect positive estimated coefficients on SSAP10R $R_{t}$ and SSAP101 $(\beta>0$, $\gamma>0) . \boldsymbol{X}_{i t}$ is a vector of firm-level control variables. $\boldsymbol{I}_{s}$ represents state of domicile fixed effects. $\epsilon_{i t}$ is a random error term.

In addition to our variables of interest, we also control for other factors that could potentially affect an insurer's level of admitted DTAs. Specifically, we include size (Sizeit), profitability (PTROA $A_{i t}$ ), leverage (Liabilities/Surplusit), composition of investments (\%Annuitiesit), reinsurance (Reinsurance ${ }_{i t}$ ), competition (Product Herf $f_{i t}$, foreign operations (Foreign ${ }_{i t}$ ), the insurer's ownership structure $\left(\right.$ Mutual $_{i t}$ ), whether a firm is affiliated with other insurers (Groupit), and capital structure (Premiums/Surplusit).

For our second hypothesis, we examine whether firms with lower RBC ratios include a greater proportion of their total DTAs in regulatory capital as compared to other insurers. Firms with lower RBC ratios are closer to regulatory action and insolvency than their peers and have more incentive to use the discretion in the regulation to manage their level of admitted DTAs, and thus, their $\mathrm{RBC}$ ratios:

$$
\begin{gathered}
D T A_{i t}=\beta S S A P 10 R_{t}+\gamma S S A P 101_{t}+\psi \text { Low RBC } i t+\omega S S A P 10 R_{t} * \text { Low RBC } i t \\
+\zeta S S A P 101_{t} * \text { Low } R B C_{i t}+\phi \boldsymbol{X}_{i t}+\boldsymbol{I}_{s}+\epsilon_{i t}
\end{gathered}
$$

Low $R B C_{i t}$ is a binary variable equal to one if firm i's risk-based capital ratio was in the lowest 25 percent of firms in year $t$ and zero otherwise. ${ }^{21,22}$ If firms with low RBC ratios include a greater proportion of their overall DTAs in regulatory capital, we expect positive estimated coefficients on Low $R B C$ it $(\psi>0)$. If new regulation allows these firms even greater opportunity to manage

\footnotetext{
${ }^{21}$ Our results are consistent if we use firms in the lowest tercile of the RBC ratio distribution.

${ }^{22}$ As we note above, while most insurers are not near the legal threshold that mandates regulator intervention, regulators are not required to wait until a firm is beyond the threshold to intervene. State laws give regulators substantial power to intervene if they believe a firm's financial condition has deteriorated. Additionally, firms face incentives outside of regulatory oversight to report relatively high levels of risk-based capital, such as higher financial strength ratings.
} 
their level of admitted DTAs as compared to SSAP 10, we expect positive estimated coefficients on SSAP10R ${ }_{t}^{*}$ Low $R B C_{i t}$ and SSAP101 ${ }_{t}^{*} \operatorname{Low} R B C_{i t}(\omega>0, \zeta>0)$. We include the same vector of control variables from equation (2). All other variables are as previously defined. In both equations (2) and (3), we cluster standard errors by firm.

\section{Admitted DTAs and Future Profitability}

For our third hypothesis, we begin by examining the relation between a firm's level of admitted DTAs and future profitability (H3a). To test this hypothesis, we estimate the following model using OLS:

$$
\operatorname{PTROA}_{i t+n}=\beta D T A_{i t}+\phi \boldsymbol{X}_{i t}+\boldsymbol{I}_{t}+\epsilon_{i t}
$$

$P_{T R O A}{ }_{t+n}$ equals pretax income scaled by total assets in years $t+1, t+2$, and $t+3 .{ }^{23} D T A_{i t}$ is as previously defined. If, on average, insurers are including DTAs in admitted assets that they expect to realize within the statutory window, we expect a positive association between the level of admitted DTAs and future profitability $(\beta>0)$. $\boldsymbol{X}_{i t}$ is a vector of firm-level control variables. We include the same vector of control variables from equations (2) and (3). It represents year fixed effects. $\epsilon_{i t}$ is a random error term.

Next, we examine whether the level of admitted DTAs reflects future firm profitability for firms with the greatest incentives to manage their regulatory capital ratios (H3b). More specifically, we examine if life insurers with low RBC ratios and high levels of DTAs in admitted assets actually realize DTAs to the extent that they are included in regulatory capital. To test this hypothesis, we estimate the following model using OLS:

$$
\begin{aligned}
\text { PTROA }_{i t+n}= & \beta \text { High DTAs } \\
& +\gamma \text { Low RBC } \\
& +\boldsymbol{I}_{t}+\epsilon_{i t}
\end{aligned}
$$

\footnotetext{
${ }^{23}$ The new regulations increased the time period for including DTAs expected to be realized from one to three years.
} 
$P T R O A_{i t+n}$ and Low RBCit are as previously defined. We set High DTAsit equal to one for firms in the top quartile of the distribution for $D T A_{i t}$, and zero otherwise. If insurers with the lowest RBC ratios and admitted DTAs in the top quartile of the distribution include DTAs in excess of those eventually realized, we expect a negative relation between our interaction term and future profitability $(\psi<0)$. We include the same set of control variables as in equations (2) through (4). $\boldsymbol{X}_{i t}$ is a vector of firm-level control variables. $\boldsymbol{I}_{t}$ represents year fixed effects. $\epsilon_{i t}$ is a random error term. Appendix A contains detailed definitions for all variables used in regression analysis.

\section{RESULTS}

\section{Descriptive Statistics}

We present descriptive statistics for our sample in Table 3. The average life insurer reports 39.1 percent of total DTAs as admitted DTAs (DTAit). The $10^{\text {th }}$ percentile is zero (untabulated), indicating that at least 10 percent of insurer-years in our sample report no admitted DTAs as part of their regulatory capital ratio.

\section{[Insert Table 3 here]}

In Table 4 we provide correlations for the variables used in our study. We report Pearson correlations in the bottom triangles and Spearman correlations in the upper triangles. Bolded figures are significant at the 0.10 percent level. We find a negative and statistically significant association between $D T A_{i t}$ and $R B C$ Ratioit, suggesting that firms with lower RBC ratios, and potentially greater motivation to avoid regulatory scrutiny, include a greater percent of total DTAs

as admitted assets. We also find a positive and statistically significant association between DTA it and PTROA , suggesting that firms that include a greater percent of total DTAs as admitted assets are also more profitable, consistent with the average life insurer admitting DTAs they expect to 
realize. However, since correlations do not account for other potentially confounding factors that could determine a firm's reported DTAs, we next provide a multivariate examination of the determinants and consequences of DTAs.

[Insert Table 4 here]

\section{Determinants of DTAs Across Accounting Standards}

We present empirical estimation of equation (2) in Table 5, Panel A. We report standard errors to the right of estimated coefficients. The first notable result in Table 5 is that coefficient estimates on the SSAP10R $t$ and SSAP101 indicator variables are positive and statistically significant. Since positive coefficient estimates indicate higher levels of admitted deferred tax assets following a change in regulation, these results suggest that life insurers took advantage of the increased discretion afforded by regulators during the SSAP 10R and SSAP 101 regimes when they had sufficient total DTAs to do so. The estimated coefficients in column (1) suggest that following the implementation of statutory rules allowing greater inclusion of DTAs, life insurers increased admitted DTAs by 8.5 to 12.3 percent (representing a 25 percent increase over prior levels). ${ }^{24}$

[Insert Table 5 here]

We present empirical estimation of equation (3) in Table 5, Panel B. Notably, we find that the estimated coefficient on Low $R B C$ it is negative and statistically significant. This finding suggests that life insurers with relatively low levels of risk-based capital are more likely to report lower admitted DTAs after controlling for other factors, which is consistent with these firms

\footnotetext{
${ }^{24}$ To clarify, our coefficient estimates on SSAP 10R and SSAP 101 indicators are between 0.085 and 0.123 , indicating that, all else equal, the percentage of admitted DTAs increases by 8.5 to 12.3 percent during these regulatory periods for life insurers (with the SSAP 10 period being the omitted category). The average ratio of admitted DTAs to total DTAs in the SSAP 10 period is just under 40 percent. An increase from 40 percent to 50 percent is, therefore, around a 25 percent increase in admitted DTAs.
} 
including DTAs that they expect to be realized in the SSAP 10 period. However, we find that firms with relatively low levels of risk-based capital include incrementally greater levels of DTAs in admitted assets as compared to their peers with the passage of both SSAP 10R and SSAP 101the coefficients on the interaction terms $\left(S S A P 101_{t}^{*}\right.$ Low $R B C_{i t}$ and $S S A P 10 R_{t}{ }^{*}$ Low $\left.R B C_{i t}\right)$ are positive and statistically significantly. Overall, our results suggest that while all life insurers increased DTAs during SSAP 10R and SSAP 101, relatively financially weak life insurers use the increased discretion to include an even greater share of DTAs in total adjusted capital, raising concerns that these life insurers may be including DTAs above what they expect to realize within the prescribed window of time. We further examine this possibility with our next set of tests.

\section{Admitted DTAs and Firm Profitability}

Hypothesis H3a examines the relation between admitted DTAs and future profitability. We present empirical estimation of equation (4) in Table 6. We report standard errors below estimated coefficients. In each column, we find a positive and statistically significant association between a firm's level of admitted DTAs and future profitability in years $t+1, t+2$, and $t+3$. Overall, these results suggest that, on average, firms admit DTAs into regulatory capital that they expect to be able to realize within the defined statutory time frame.

[Insert Table 6 here]

Hypothesis H3b examines if life insurers that are most likely to be facing increased regulatory scrutiny include DTAs in admitted assets in excess of what they are able to realize. We present an empirical estimation of equation (5) in Table 7. In each column, we find a positive association between High DTAsit and future profitability in years $t+1, t+2$, and $t+3$, suggesting that firms in the top quartile of admitting DTAs into regulatory capital tend to have greater future profitability. This result is consistent with firms including DTAs that they are likely able to realize. 
However, the interaction on High $D T A s_{i t}{ }^{*}$ Low $R B C$ it is negative and statistically significant in years $t+2$ and $t+3$, indicating that firms in the bottom quartile of RBC ratio that include a greater proportion of DTAs in regulatory capital have incrementally lower future profitability. This result suggests that these firms with the lowest RBC ratios may be including DTAs in excess of what they expect to realize.

[Insert Table 7 here]

\section{ADDITIONAL ANALYSIS}

\section{Identification and the Financial Crisis}

In this section, we conduct additional tests to rule out the effects of the financial crisis as the primary driver of our results by (1) identifying a control group subject to the same concurrent economic and regulatory forces that do not experience a change in DTA standards, and (2) dropping various years surrounding the financial crisis. While we only use firms reporting positive net income in our primary tests, excluding financial crisis years allows us to rule out the possibility that firms reported income for regulatory purposes and losses for tax purposes, thus potentially creating tax net operating loss carryforwards during the economic downturn.

Given that SSAP 10R and SSAP 101 affected all insurers at the same time, in Table 8 we use U.S. banks as a control group to provide further identification that the change in regulation, and not some other contemporaneous event such as the financial crisis, drives the increase in the level of admitted DTAs. During our sample period, U.S. banks also include DTAs in their Tier 1 risk-based capital calculation based on the lesser of the amount of DTAs that the bank is expected to realize within one year or 10 percent of Tier 1 capital, which is similar to U.S. insurers' limitations under SSAP 10. Additionally, the American Bankers Association and the Clearing 
House Association L.L.C. wrote to the Board of Governors of the Federal Reserve System in September 2009 asking the Federal Reserve System to revisit the risk-based capital guidelines and regulations for banks with a specific focus on relaxing the limitations on DTA inclusion in riskbased capital (American Bankers Association 2009). Since U.S. banks experienced similar economic conditions leading up to and following the financial crisis, petitioned for increased inclusion of DTAs in risk-based capital, and failed to receive regulatory forbearance with respect to DTA inclusion, we view U.S. banks as having many characteristics that make them a strong control sample for comparison to our sample of U.S. insurers.

We use the FR Y-9C bank data for our sample of banks. ${ }^{25}$ We exclude banks with missing or nonpositive values for total assets or total equity and banks with negative pretax income. We additionally exclude banks with less than $\$ 500$ million in total assets (Gallemore 2012). ${ }^{26}$ These sample cuts result in a bank sample consisting of 5,906 firm year observations for 910 unique banks from 2003 through 2016. ${ }^{27}$ Similar to Table 5, Panel A, our dependent variable of interest in Table 8 equals admitted DTAs (Tier 1 DTAs for bank holding companies) scaled by total DTAs. ${ }^{28}$ We include an indicator variable, Insureri, that is equal to one for U.S. insurer observations and zero for U.S. bank holding company observations. We interact Insurer $i$ with $S S A P 10 R_{t}$ and $S S A P 101_{t}$ to examine if U.S. insurers reported relatively higher admitted DTAs

\footnotetext{
${ }^{25}$ One of the limitations of using banks as a control group is that we perform our bank analysis at the holding company level, while we perform our insurer analysis at the individual company level. We do so because regulators monitor regulatory capital at the holding company level for banks and the individual company level for insurers, allowing us to more directly examine the effect of the changes in insurer regulation on inclusion of the level of admitted DTAs.

${ }^{26}$ Gallemore (2012) reports his results are consistent while excluding banks with less than $\$ 500$ million, \$750 million, and $\$ 1$ billion in assets. To maintain as many small banks as is practical, given that the unit of observation for our insurers is at the individual company level, we choose the smallest of these cutoffs.

${ }^{27}$ Our life insurer sample in these tests represents 334 unique insurers and 2,776 firm-year observations. Our sample increases in these tests compared to our main tests since we use a different set of control variables that are calculable for banks (e.g., we cannot construct \%Annuity for banks).

${ }^{28}$ As Gallemore (2012) notes, banks are not required to explicitly report the amount of DTAs that they include in Tier 1 regulatory capital (i.e., the analogue to an insurer's admitted DTAs). Therefore, we calculate Tier 1 DTAs as total DTAs minus non-Tier 1 DTAs.
} 
following regulatory changes allowing them to do so. We report positive estimated coefficients on

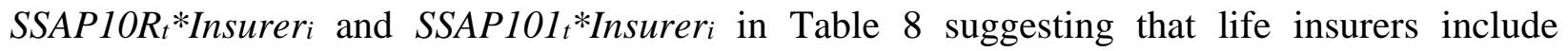
incrementally more DTAs as a percentage of total DTAs in regulatory capital than U.S. banks following adoption of both SSAP 10R and SSAP 101. These results provide some evidence that the increase in admitted DTAs following passage of these regulations relates to the regulatory change and not some other contemporaneous event.

[Insert Table 9 here]

Next, we examine whether our primary results in Table 5 are driven by a subset of years in our sample. First, we estimate equations (2) and (3) on our sample excluding calendar years 2003 through 2006 to examine if our results suggesting an increase in admitted DTAs following implementation of SSAP 10R and SSAP 101 are driven by pre-financial crisis activity. Next, we estimate equations (2) and (3) on our sample excluding calendar years 2007 and 2008 to exclude the immediate effects of the financial crisis and potential increases in DTAs relating to additional tax net operating losses. Finally, we estimate equations (2) and (3) on our sample excluding calendar years 2007 through 2010 to allow firms additional years to use any tax loss carryforwards generated during the financial crisis that may be influencing a firm's level of admitted DTAs and our results.

We report results from estimation of equation (2) in Table 9 columns (1), (3), and (5). In each specification, we continue to find significantly positive estimated coefficients on SSAP10Rt and SSAP101, supporting that the finding in Table 5 that insurers increase their admitted DTAs following each regulatory change is not driven by a simultaneous confounding event, such as the financial crisis. In Table 9, columns (2), (4), and (6), we report results from estimation of equation (3) on each alternate sample period. We continue to find evidence that life insurers with relatively 
low levels of risk-based capital are more likely to report higher admitted DTAs after controlling for other factors, which is consistent with these firms reporting higher admitted DTAs to avoid potential regulatory scrutiny.

We recognize that each analysis has its own strengths and weaknesses. However, we believe that all of this evidence taken together helps to provide sharper identification and further isolates that the documented increase in admitted assets is a result of the changes in regulatory standards and not other contemporaneous events.

[Insert Table 9 here]

\section{Disentangling Regulation from Increases in Total Deferred Tax Assets}

One alternative explanation for the results documented in Table 5 is that firms increase their total deferred tax assets over time, and, as a result, we are capturing the impact of factors that increase a firm's total DTAs, and not the effect of changes in regulation. To provide evidence contrary to this explanation, we estimate equations (2) and (3) on insurers' levels of nonadmitted DTAs. If we are capturing an overall increase in total DTAs, we would expect a positive relation between an insurer's level of nonadmitted DTAs and the passage of SSAP 10R and SSAP 101. In untabulated analysis, we find that an insurer's level of nonadmitted DTAs significantly decreases following adoption of SSAP 10R and SSAP 101. Taken together with the results in Table 5, these results suggest that we are not capturing an overall increase in total DTAs. Instead, firms appear to reallocate their total DTAs from nonadmitted to admitted assets under SSAP 10R and SSAP101. We believe this result is consistent with insurers classifying more DTAs as admitted assets and provides some support that an overall increase in total DTAs does not fully explain the increase in admitted DTAs. 


\section{CONCLUSION}

Regulators' primary goal is to ensure financial institution stability and solvency. Therefore, regulators are interested in ensuring that firms have sufficient assets to fulfill obligations. Insurance regulators have designed accounting standards and risk-based regulatory capital requirements with this goal in mind—assets that cannot be used to fulfill policyholder obligations are not included as regulatory capital. Using a setting in which regulatory changes allow managers more discretion, we find evidence that life insurance companies increase the inclusion of DTAs in regulatory capital used to determine whether financial institutions have sufficient means to meet their obligations. Importantly, companies with relatively low levels of regulatory capital include higher levels of DTAs in regulatory capital, potentially as a means of avoiding regulatory scrutiny. These insurers also appear to admit additional DTAs as a means of incrementally improving their regulatory capital ratios and not as a reflection of their expectations for future realization. These results support concerns that the inclusion of less liquid assets such as DTAs may cause financial institutions to appear financially healthier than their true underlying positions.

Our findings have important implications for regulators. Consistent with Skinner (2008) and Gallemore (2012), our results suggest that, when permitted, financial institutions will use greater discretion over DTA reporting to improve their perceived capital position. If this is the case, new regulation increasing the inclusion of DTAs for regulatory capital purposes may increase the risk associated with these financial firms. Therefore, the role of DTAs in regulatory capital is relevant as bank and insurance regulators consider whether and to what extent DTAs should be includable, particularly given prior evidence of the dangers of doing so (Skinner 2008; Gallemore 2012). Our results should be informative to regulators given the overall importance of financial institutions in the economy. 


\section{Appendix A \\ Variable definitions}

\begin{tabular}{|c|c|c|}
\hline \multicolumn{3}{|c|}{ Variables of Interest } \\
\hline DTA & $=$ & $\begin{array}{l}\text { Firm } i \text { 's admitted deferred tax assets in year } t \text { scaled by total deferred tax } \\
\text { assets. }\end{array}$ \\
\hline Insurer & $=$ & $\begin{array}{l}\text { A binary variable equal to one for insurance firm observations and zero for } \\
\text { bank holding company observations. }\end{array}$ \\
\hline Low $R B C$ & $=$ & $\begin{array}{l}\text { A binary variable equal to one if firm } i \text { 's risk-based capital ratio was in the } \\
\text { lowest } 25 \text { percent of firms in year } t \text { and zero otherwise. }\end{array}$ \\
\hline RBC Ratio & $=$ & The ratio of firm i's total adjusted capital to risk-based capital in year $t$. \\
\hline SSAP10R & $=$ & $\begin{array}{l}\text { A binary variable equal to one during years when SSAP } 10 \mathrm{R} \text { was enforced } \\
\text { and zero otherwise. }\end{array}$ \\
\hline SSAP101 & $=$ & $\begin{array}{l}\text { A binary variable equal to one during years when SSAP } 101 \text { was enforced } \\
\text { and zero otherwise. }\end{array}$ \\
\hline \multicolumn{3}{|c|}{ General Control Variables } \\
\hline \%Annuities & $=$ & The percent of firm $i$ 's premiums written in annuities in year $t$. \\
\hline Group & $=$ & $\begin{array}{l}\text { A binary variable equal to one if a firm was organized as a member of a } \\
\text { group in year } t \text { and zero otherwise. }\end{array}$ \\
\hline Liabilities/Surplus & $=$ & Firm i's total liabilities divided by total surplus in year $t$. \\
\hline $\ln$ (Assets) & $=$ & The natural log of total assets in year $t$. \\
\hline Mutual & $=$ & $\begin{array}{l}\text { A binary variable equal to one if firm } i \text { was organized as a mutual in year } t \\
\text { and zero otherwise. }\end{array}$ \\
\hline Premiums/Surplus & $=$ & Firm $i$ 's net premiums written divided by total surplus in year $t$. \\
\hline Prod Herf & $=$ & $\begin{array}{l}\text { A Herfindahl index based on firm i's premiums written across } 11 \text { lines of } \\
\text { business for life insurance firms in year } t \text {. }\end{array}$ \\
\hline Reinsurance & $=$ & $\begin{array}{l}\text { Firm } i \text { 's reinsurance ceded divided by the sum of direct premiums written } \\
\text { and reinsurance assumed in year } t \text {. }\end{array}$ \\
\hline PTROA & $=$ & Firm $i$ 's net income in year $t$ divided by assets in year $t-1$. \\
\hline
\end{tabular}




\section{REFERENCES}

Acharya, V. V., and S. G. Ryan. 2016. Banks’ financial reporting and financial system stability. Journal of Accounting Research 54: 277-340.

Barrese, J., and J. M. Nelson. 1994. Some consequences of insurer insolvencies. Journal of Insurance Regulation 13: 3-18.

Bauman, C. C., M. P. Bauman, and R. F. Halsey. 2001. Do firms use the deferred tax asset valuation allowance to manage earnings? Journal of the American Taxation Association 23: 27-48.

Beatty, A., S. L. Chamberlain, and J. Magliolo. 1995. Managing financial reports of commercial banks: The influence of taxes, regulatory capital, and earnings. Journal of Accounting Research 33: 231-261.

Becker, B., M. M. Opp, and F. Saidi. 2021. Regulator forbearance in the U.S. insurance industry: The effects of removing capital requirements for an asset class. Review of Financial Studies Forthcoming.

Bhattacharya, S., A. W. Boot, and A. V. Thakor. 1998. The economics of bank regulation. Journal of Money, Credit and Banking 30: 745-770.

Billio, M., M. Getmansky, A. W. Lo, and L. Pelizzon. 2012. Econometric measures of connectedness and systemic risk in the finance and insurance sectors. Journal of Financial Economics 104: 535-559.

Campello, M., E. Giambona, J. R. Graham, and C. R. Harvey. 2011. Liquidity management and corporate investment during a financial crisis. Review of Financial Studies 24: 1944-1979.

Christensen, T. E., G. H. Paik, and E. K. Stice. 2008. Creating a bigger bath using the deferred tax valuation allowance. Journal of Business Finance \& Accounting 35: 601-625.

Collins, J. H., D. A. Shackelford, and J. M. Wahlen. 1995. Bank differences in the coordination of regulatory capital, earnings, and taxes. Journal of Accounting Research 33: 263-291.

Cornett, M. M., J. J. McNutt, P. E. Strahan, and H. Tehranian. 2011. Liquidity risk management and credit supply in the financial crisis. Journal of Financial Economics 101: 297-312.

Dhaliwal, D. S., C. A. Gleason, and L. F. Mills. 2004. Last-chance earnings management: Using the tax expense to meet analysts' forecasts. Contemporary Accounting Research 21: 431459.

Dhaliwal, D. S., S. E. Kaplan, R. C. Laux, and E. Weisbrod. 2013. The information content of tax expense for firms reporting losses. Journal of Accounting Research 51: 135-164.

Eastman, E. M., D. L. Eckles, and A. Van Buskirk. 2021. Accounting-based regulation: Evidence from health insurers and the Affordable Care Act. The Accounting Review 96: 231-259.

Ellul, A., C. Jotikasthira, and C. T. Lundblad. 2011. Regulatory pressure and fire sales in the corporate bond market. Journal of Financial Economics 101: 596-620.

Ellul, A., C. Jotikasthira, C. T. Lundblad, and Y. Wang. 2015. Is historical cost accounting a panacea? Market stress, incentive distortions, and gains trading. Journal of Finance 70: 2489-2538.

Epermanis, K., and S. E. Harrington. 2006. Market discipline in property/casualty insurance: Evidence from premium growth surrounding changes in financial strength ratings. Journal of Money, Credit and Banking 38: 1515-1544. 
Financial Accounting Standards Board. February 1992. Accounting for income taxes. Statement of Financial Accounting Standards No. 109 (FAS 109) Norwalk, CT.

Financial Accounting Standards Board. September 2009. Income taxes (Topic 740). Accounting Standards Update No. 2009-06. Norwalk, CT.

Flannery, M. J., and S. M. Sorescu. 1996. Evidence of bank market discipline in subordinated debenture yields: 1983-1991. Journal of Finance 51: 1347-1377.

Frank, M. M., and S. O. Rego. 2006. Do managers use the valuation allowance account to manage earnings around certain earnings targets? Journal of the American Taxation Association 28: 43-65.

Gallemore, J. 2012. Deferred tax assets and bank regulatory capital. Working paper. University of North Carolina at Chapel Hill. Available at https://www.fdic.gov/bank/analysis/cfr/bank-research-conference/annual12th/gallemore.pdf.

Gaver, J. J., and J. S. Paterson. 1999. Managing insurance company financial statements to meet regulatory and tax reporting goals. Contemporary Accounting Research 16: 207-241.

Government Accountability Office (GAO). 2013. Insurance markets: Impacts of and regulatory response to the 2007-2009 financial crisis. GAO-13-583.

Grace, M. F., R. W. Klein, and R. D. Phillips. 2003. Insurance company failures: Why do they cost so much? Working Paper No. 03-1. Georgia State University Center For Risk Management and Insurance Research. Available at https://ssrn.com/abstract=463103.

Grace, M. F., S. E. Harrington, and R. W. Klein. 1998. Risk-based capital and solvency screening in property-liability insurance: Hypotheses and empirical tests. Journal of Risk and Insurance 65: 213-243.

Gupta, S., R. C. Laux, and D. P. Lynch. 2016. Do firms use tax reserves to meet analysts' forecasts? Evidence from the pre- and post-FIN 48 periods. Contemporary Accounting Research 33: 1044-1074.

Hanley, K. W., and S. Nikolova. 2021. Rethinking the use of credit ratings in capital regulations: Evidence from the insurance industry. Review of Corporate Finance Studies 10: 347-401.

Hanley, K. W., A. D. Jagolinzer, and S. Nikolova. 2018. Strategic estimation of asset fair values. Journal of Accounting and Economics 66: 25-45.

Hanlon, M., and S. Heitzman. 2010. A review of tax research. Journal of Accounting and Economics 50: 127-178.

Jung, D.-J., and D. Pulliam. 2006. Predictive ability of the valuation allowance for deferred tax assets. Academy of Accounting \& Financial Studies Journal 10: 49-70.

Khan, U., S. G. Ryan, and A. Varma. 2019. Fair value versus amortized cost measurement and the timeliness of other-than-temporary impairments: Evidence from the insurance industry. The Accounting Review 94: 285-307.

Klein, R. W. 2012. Principles for insurance regulation: An evaluation of current practices and potential reforms. Geneva Papers on Risk and Insurance-Issues and Practice 37: 175199.

Koijen, R. S. J., and M. Yogo. 2015. The cost of financial frictions for life insurers. American Economic Review 105: 445-475.

Koijen, R. S. J., and M. Yogo. 2016. Shadow insurance. Econometrica 84: 1265-1287. 
Krull, L. K. 2004. Permanently reinvested foreign earnings, taxes, and earnings management. The Accounting Review 79: 745-767.

Leverty, J. T., and M. F. Grace. 2012. Dupes or incompetents? An examination of management's impact on firm distress. Journal of Risk and Insurance 79: 751-783.

Miller, G. S., and D. J. Skinner. 1998. Determinants of the valuation allowance for deferred tax assets under SFAS no. 109. The Accounting Review 73: 213-233.

Munch, P., and D. E. Smallwood. "Theory of Solvency Regulation in the Property and Casualty Insurance Industry." In G. Fromm, Editor. Studies in Public Regulation. Cambridge, MA: MIT Press. 1981.

Murray, S., and S. Nikolova. 2021. The bond pricing implications of rating-based capital requirements. Journal of Financial and Quantitative Analysis Forthcoming.

National Association of Insurance Commissioners (NAIC). 2020. Risk-based capital. The Center for Insurance Policy and Research June 24, 2020. https://content.naic.org/cipr_topics/topic_risk_based_capital.htm

Park, S., and S. Peristiani. 1998. Market discipline by thrift depositors. Journal of Money, Credit and Banking 30: 347-364.

Petroni, K. R. 1992. Optimistic reporting in the property-casualty insurance industry. Journal of Accounting and Economics 15: 485-508.

Petroni, K. R., and D. A. Shackelford. 1995. Taxation, regulation, and the organizational structure of property-casualty insurers. Journal of Accounting and Economics 20: 229-253.

PwC. 2012. Tax accounting for insurance companies.

Reilly, D. 2009. Citi, BofA show investors can't bank on capital. Bloomberg. Available at https://www.business-standard.com/article/opinion/david-reilly-citi-bofa-show-investorscan-39-t-bank-on-capital-109020101019_1.html

Schipper, K. 1989. Earnings management. Accounting Horizons 3: 91-102.

Schrand, C. M., and M. H. F. Wong. 2003. Earnings management using the valuation allowance for deferred tax assets under SFAS no. 109. Contemporary Accounting Research 20: 579611.

Schwarcz, D. 2018. Is U.S. insurance regulation unconstitutional? Connecticut Insurance Law Journal 25: 191-256.

Skinner, D. J. 2008. The rise of deferred tax assets in Japan: The role of deferred tax accounting in the Japanese banking crisis. Journal of Accounting and Economics 46: 218-239.

Society of Actuaries. 2009. ACLI update column. Taxing Times 5: 42-44.

Society of Actuaries. 2010. SSAP 10R - admittance of deferred income taxes modified in 2009. Taxing Times 6: 28-31.

Sommer, D. W. 1996. The impact of firm risk on property-liability insurance prices. Journal of Risk and Insurance 63: 501-514.

The Clearing House and American Bankers Association. Regulatory capital limits on deferred tax assets. September 25, 2009.

U.S. Department of Commerce. 2019. The international trade administration. Available at https://www.selectusa.gov/financial-services-industry-united-states.

Visvanathan, G. 1998. Deferred tax valuation allowances and earnings management. Journal of Financial Statement Analysis 3: 6-15. 
Figure 1

Admitted Deferred Tax Assets for Life Insurers: As Share of Total Deferred Tax Assets

This figure presents admitted deferred tax assets as a percentage of total deferred tax assets for life insurers from 2003 to 2016.

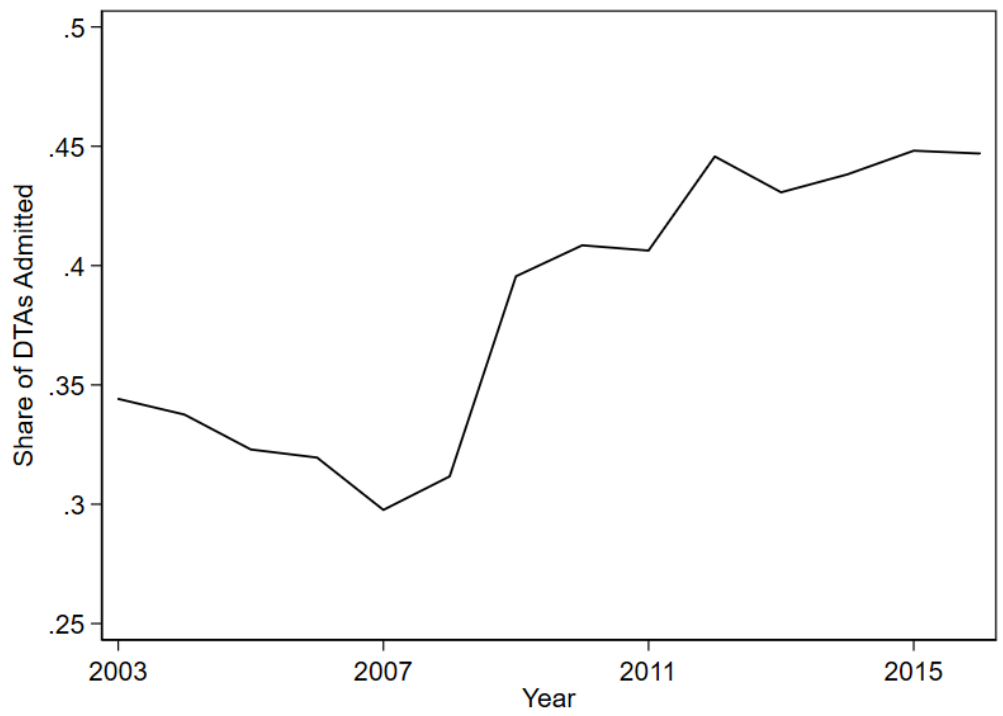

Figure 2

Admitted Deferred Tax Assets for Life Insurers: As Share of Surplus

This figure presents admitted deferred tax assets reported on life insurer balance sheets from 2003 to 2016. We report DTAs in total dollars and as a share of surplus of the reporting firms. Surplus is the difference between admitted assets and liabilities and is roughly equivalent to equity under GAAP reporting.

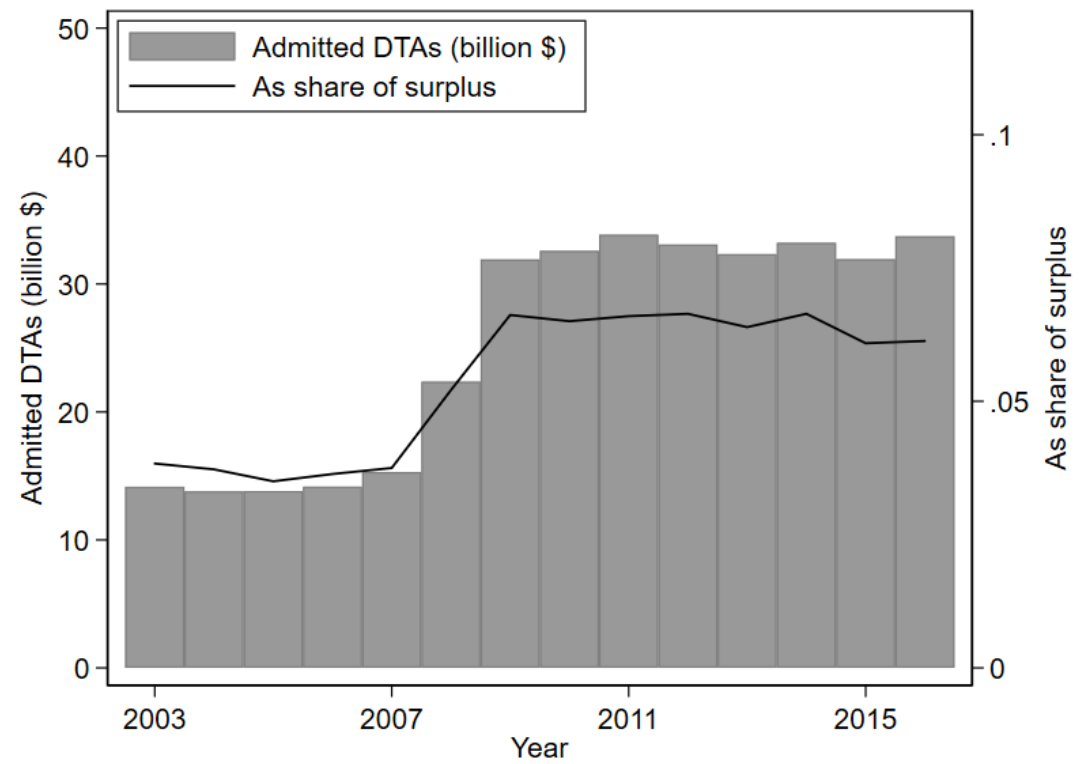




\section{Table 1}

Summary of SSAP Passage and DTA Admission Rules for Life Insurers

This table summarizes the statutory accounting updates related to the admissibility of deferred tax assets for life insurers from 2001 to present.

\begin{tabular}{|c|c|c|c|}
\hline & \multicolumn{3}{|c|}{ Regulation } \\
\hline & SSAP 10 & SSAP 10R & SSAP 101 \\
\hline Period & $2001-2008$ & $2009-2011$ & 2012-Present \\
\hline Step 1 & NOL Carrybacks & NOL Carrybacks & NOL Carrybacks \\
\hline Step 2 & $\begin{array}{c}\text { Lesser of } 1 \text { year } \\
\text { realization or } 10 \% \text { of } \\
\text { Capital }\end{array}$ & $\begin{array}{l}\text { If RBC ratio > 250\%: } \\
\text { Lesser of 3-year } \\
\text { realization (adjusted } \\
\text { for any valuation } \\
\text { allowance) or } 15 \% \text { of } \\
\text { Capital }\end{array}$ & $\begin{array}{c}\text { If RBC ratio > 300\%: } \\
\text { Lesser of 3-year } \\
\text { realization (adjusted } \\
\text { for any valuation } \\
\text { allowance) or } 15 \% \text { of } \\
\text { Capital } \\
\text { If 300\% > RBC ratio > } \\
200 \% \text { : Lessor of 1- } \\
\text { year realization or } \\
10 \% \text { of Capital } \\
\text { If RBC ratio }<200 \%: \\
\text { Zero DTAs }\end{array}$ \\
\hline Step 3 & Offset by DTLs & $\begin{array}{l}\text { Offset by DTLs of } \\
\text { same character }\end{array}$ & $\begin{array}{l}\text { Offset by DTLs of } \\
\text { same character }\end{array}$ \\
\hline
\end{tabular}




\section{Table 2}

Sample Selection Table

This table summarizes our sample selection process.

\begin{tabular}{lr}
\hline & Observations \\
\hline Firm-years in life Annual Statements from 2003 to 2016 & 12,245 \\
Less firm-years with missing or non-positive assets or surplus & $(122)$ \\
Less firms missing risk-based capital information & $(373)$ \\
Less firm-years with insufficient data to calculate variables & $(1,117)$ \\
Less firms with loss years during sample & $(8,128)$ \\
\hline Final Life Insurer Sample (300 unique firms) & 2,505 \\
\hline
\end{tabular}




\section{Table 3}

Descriptive Statistics

This table contains descriptive statistics for our sample of 2,505 observations for life insurers. See Appendix A for variable definitions.

\begin{tabular}{lccccc}
\hline \multicolumn{1}{c}{ Variable } & Mean & Std. & $25^{\text {th }}$ Pctl & $50^{\text {th }}$ Pctl & $75^{\text {th }}$ Pctl \\
\hline DTA & 0.3910 & 0.3444 & 0.0890 & 0.3131 & 0.6356 \\
Size & 19.157 & 2.5449 & 17.250 & 19.046 & 20.926 \\
PTROA & 0.0630 & 0.0797 & 0.0152 & 0.0326 & 0.0755 \\
Liabilities/Surplus & 5.7718 & 7.7617 & 0.8627 & 2.8959 & 8.0337 \\
\%Annuities & 0.1381 & 0.2832 & 0.0000 & 0.0000 & 0.0705 \\
Reinsurance & 0.1829 & 0.2707 & 0.0009 & 0.0466 & 0.2558 \\
Product Herf & 0.8314 & 0.1395 & 0.7151 & 0.8337 & 0.9823 \\
Foreign & 0.4966 & 0.5001 & 0.0000 & 0.0000 & 1.0000 \\
Mutual & 0.0327 & 0.1780 & 0.0000 & 0.0000 & 0.0000 \\
Group & 0.7916 & 0.4062 & 1.0000 & 1.0000 & 1.0000 \\
Premiums/Surplus & 1.4977 & 1.9011 & 0.2240 & 0.8446 & 2.1058 \\
RBC Ratio & 40.076 & 103.36 & 7.9972 & 12.155 & 23.870 \\
\hline
\end{tabular}




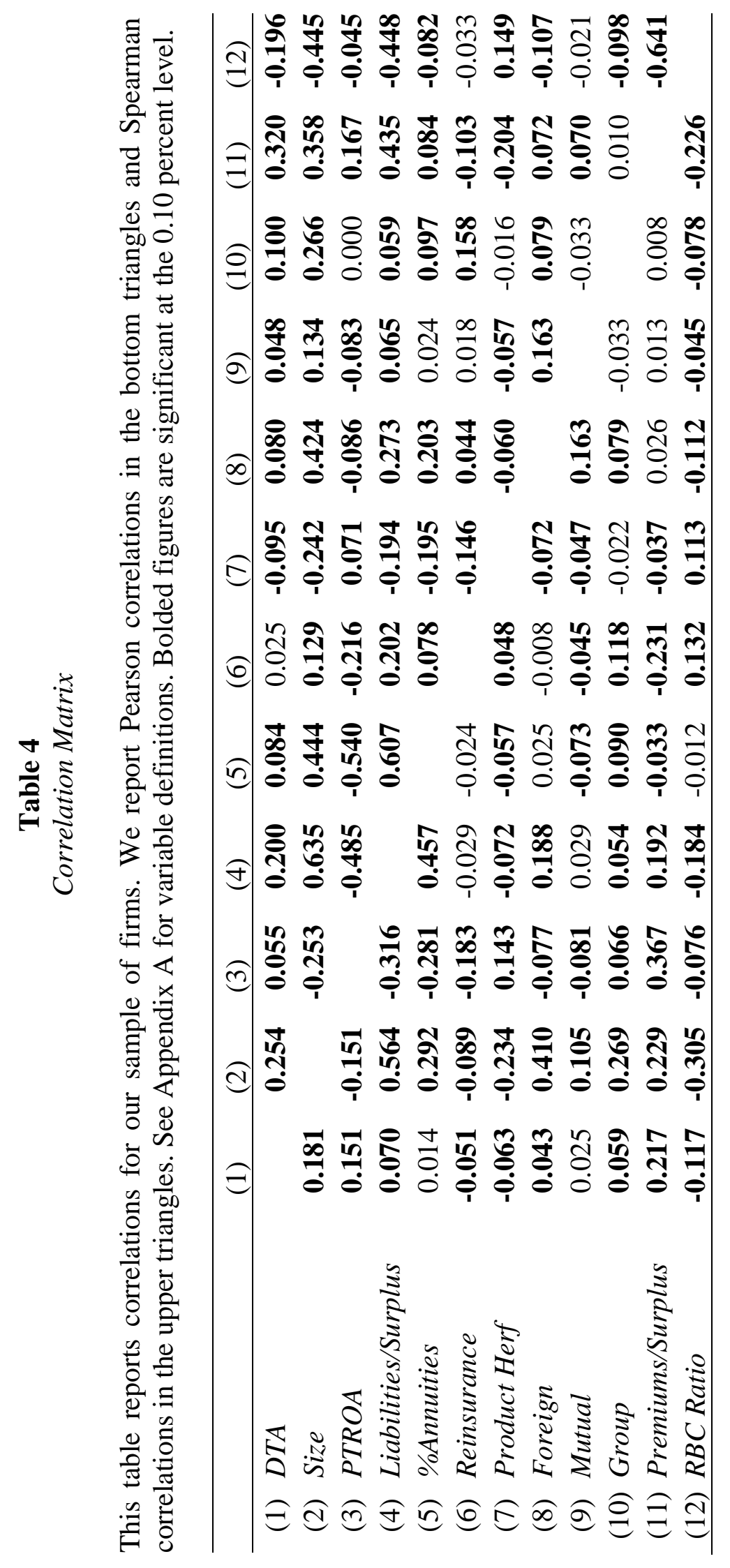


Table 5

Life Insurers' Inclusion of DTAs in Regulatory Capital

This table reports results from examination of life insurers' inclusion of DTAs in regulatory capital. Panel A reports results from an OLS regression of equation (2) and Panel B reports results from an OLS regression of equation (3). DTA equals a firm's admitted deferred tax assets divided by total deferred tax assets. SSAP10R and SSAP101 are binary variables equal to one during years when SSAP 10R and SSAP 101 were enforced, respectively, and zero otherwise. Low RBC is a binary variable equal to one if the firm's RBC ratio in year $t$ is in the bottom quartile, and zero otherwise. See Appendix A for additional variable definitions. Specifications include state fixed effects. *, **, *** indicate statistical significance at the $0.10,0.05$, and 0.01 levels, respectively (two-tailed tests). Standard errors are clustered by firm and are presented in parentheses under coefficient estimates. We winsorize all continuous explanatory variables at one and 99 percent.

\begin{tabular}{|c|c|c|c|c|c|c|}
\hline & \multicolumn{6}{|c|}{ Dependent Variable: DTA } \\
\hline & \multicolumn{3}{|c|}{ Panel A, Equation (2) } & \multicolumn{3}{|c|}{ Panel B, Equation (3) } \\
\hline & \multicolumn{3}{|c|}{$(1)$} & \multicolumn{3}{|c|}{$(2)$} \\
\hline & Est. Coe & & $\begin{array}{r}\text { Std. } \\
\text { Error } \\
\end{array}$ & Est. Coef & & $\begin{array}{r}\text { Std. } \\
\text { Error }\end{array}$ \\
\hline SSAP10R & 0.0849 & $* * *$ & 0.023 & 0.0662 & $* *$ & 0.026 \\
\hline SSAP101 & 0.1229 & $* * *$ & 0.028 & 0.1004 & $* * *$ & 0.031 \\
\hline Low $R B C$ & & & & -0.0750 & $*$ & 0.042 \\
\hline SSAP10R*Low RBC & & & & 0.1153 & $* *$ & 0.056 \\
\hline SSAP101*Low RBC & & & & 0.1395 & $* *$ & 0.062 \\
\hline Size & 0.0198 & $*$ & 0.010 & 0.0198 & $*$ & 0.010 \\
\hline PTROA & 0.5876 & $* * *$ & 0.183 & 0.5752 & $* * *$ & 0.181 \\
\hline Liabilities/Surplus & 0.0015 & & 0.002 & 0.0014 & & 0.002 \\
\hline \%Annuities & -0.0310 & & 0.050 & -0.0332 & & 0.050 \\
\hline Reinsurance & 0.0535 & & 0.054 & 0.0571 & & 0.054 \\
\hline Product Herf & -0.1130 & & 0.106 & -0.1066 & & 0.106 \\
\hline Foreign & -0.0057 & & 0.035 & -0.0123 & & 0.035 \\
\hline Mutual & 0.0723 & & 0.077 & 0.0757 & & 0.076 \\
\hline Group & 0.0161 & & 0.046 & 0.0160 & & 0.046 \\
\hline Premiums/Surplus & 0.0249 & $* * *$ & 0.009 & 0.0270 & $* *$ & 0.011 \\
\hline State FE & & Yes & & & Yes & \\
\hline $\mathrm{R}^{2}$ & & $18.88 \%$ & & & $19.36 \%$ & \\
\hline F-Stat & & 5.28 & & & 4.91 & \\
\hline Observations & & 2,504 & & & 2,504 & \\
\hline
\end{tabular}




\section{Table 6}

\section{DTAs and Future Profitability}

This table reports results from an examination of the association between a firm's level of admitted DTAs and future firm profitability using equation (4). DTA equals a firm's admitted deferred tax assets divided by total deferred tax assets. PTROA equals pretax income scaled by total assets in years $t+1$ through $t+3$. See Appendix A for additional variable definitions. Specifications include year fixed effects. *, **, *** indicate statistical significance at the $0.10,0.05$, and 0.01 levels,

\begin{tabular}{|c|c|c|c|c|c|c|}
\hline \multicolumn{7}{|c|}{ Dependent Variable: Future PTROA } \\
\hline & $t+1$ & & $t+2$ & & $t+3$ & \\
\hline \multirow[t]{2}{*}{ DTA } & 0.0104 & $* * *$ & 0.0097 & $* *$ & 0.0117 & $* *$ \\
\hline & $(0.003)$ & & $(0.004)$ & & $(0.006)$ & \\
\hline \multirow[t]{2}{*}{ Size } & -0.0015 & ** & -0.0015 & $* *$ & -0.0013 & \\
\hline & $(0.001)$ & & $(0.001)$ & & $(0.001)$ & \\
\hline \multirow[t]{2}{*}{ Liabilities/Surplus } & -0.0009 & $* * *$ & -0.0009 & $* * *$ & -0.0011 & $* * *$ \\
\hline & $(0.000)$ & & $(0.000)$ & & $(0.000)$ & \\
\hline \multirow[t]{2}{*}{$\%$ Annuities } & -0.0089 & $* * *$ & -0.0126 & $* * *$ & -0.0164 & $* * *$ \\
\hline & $(0.003)$ & & $(0.003)$ & & $(0.003)$ & \\
\hline \multirow[t]{2}{*}{ Reinsurance } & -0.0091 & ** & -0.0064 & & -0.0105 & $*$ \\
\hline & $(0.004)$ & & $(0.004)$ & & $(0.006)$ & \\
\hline \multirow[t]{2}{*}{ Product Herf } & 0.0150 & $* *$ & 0.0117 & & 0.0064 & \\
\hline & $(0.007)$ & & $(0.008)$ & & $(0.009)$ & \\
\hline \multirow[t]{2}{*}{ Foreign } & 0.0032 & & 0.0047 & $*$ & 0.0026 & \\
\hline & $(0.002)$ & & $(0.003)$ & & $(0.003)$ & \\
\hline \multirow[t]{2}{*}{ Mutual } & -0.0112 & $* * *$ & -0.0120 & $* * *$ & -0.0154 & $* * *$ \\
\hline & $(0.002)$ & & $(0.003)$ & & $(0.003)$ & \\
\hline \multirow[t]{2}{*}{ Group } & 0.0073 & $* * *$ & 0.0094 & $* * *$ & 0.0142 & $* * *$ \\
\hline & $(0.002)$ & & $(0.003)$ & & $(0.003)$ & \\
\hline \multirow[t]{2}{*}{ Premiums/Surplus } & 0.0052 & $* * *$ & 0.0052 & $* * *$ & 0.0062 & $* * *$ \\
\hline & $(0.001)$ & & $(0.001)$ & & $(0.002)$ & \\
\hline \multirow[t]{2}{*}{$\mathrm{PTROA}_{t}$} & 0.7002 & $* * *$ & 0.6618 & $* * *$ & 0.5753 & $* * *$ \\
\hline & $(0.039)$ & & $(0.041)$ & & $(0.054)$ & \\
\hline Year FE & Yes & & Yes & & Yes & \\
\hline $\mathrm{R}^{2}$ & $70.94 \%$ & & $68.71 \%$ & & $61.81 \%$ & \\
\hline F-Stat & 156.29 & & 151.07 & & 106.91 & \\
\hline Observations & 2,215 & & 1,968 & & 1,744 & \\
\hline
\end{tabular}


Table 7

DTAs and Future Profitability: Low RBC Firms

This table reports results from examination of the association between low RBC insurers' inclusion of DTAs in regulatory capital and future profitability using equation (5). High DTAs is a binary variable equal to one if the firm's proportion of admitted DTAs is in the top quartile, and zero otherwise. Low $R B C$ is a binary variable equal to one if the firm's RBC ratio in year $t$ is in the bottom quartile, and zero otherwise. PTROA equals pretax income scaled by total assets in years $t+1$ through $t+3$. See Appendix A for additional variable definitions. Specifications include year fixed effects. ${ }^{*}$, **, *** indicate statistical significance at the $0.10,0.05$, and 0.01 levels, respectively (two-tailed tests). Standard errors are clustered by firm and are presented in parentheses under coefficient estimates. We winsorize all continuous explanatory variables at one and 99 percent.

\begin{tabular}{|c|c|c|c|c|c|c|}
\hline & $t+1$ & & $t+2$ & & $t+3$ & \\
\hline \multirow[t]{2}{*}{ Low $R B C$} & 0.0036 & & 0.0085 & $* *$ & 0.0029 & \\
\hline & $(0.003)$ & & $(0.004)$ & & $(0.005)$ & \\
\hline \multirow[t]{2}{*}{ High DTAs } & 0.0091 & $* * *$ & 0.0097 & $* * *$ & 0.0131 & $* * *$ \\
\hline & $(0.003)$ & & $(0.003)$ & & $(0.004)$ & \\
\hline \multirow[t]{2}{*}{ Low RBC * High DTAs } & -0.0040 & & -0.0142 & $* *$ & -0.0135 & $*$ \\
\hline & $(0.005)$ & & $(0.007)$ & & $(0.007)$ & \\
\hline \multirow[t]{2}{*}{ Size } & -0.0014 & $* *$ & -0.0014 & $* *$ & -0.0011 & \\
\hline & $(0.001)$ & & $(0.001)$ & & $(0.001)$ & \\
\hline \multirow[t]{2}{*}{ Liabilities/Surplus } & -0.0009 & $* * *$ & -0.0009 & $* * *$ & -0.0011 & $* * *$ \\
\hline & $(0.000)$ & & $(0.000)$ & & $(0.000)$ & \\
\hline \multirow[t]{2}{*}{ \%Annuities } & -0.0085 & $* * *$ & -0.0117 & $* * *$ & -0.0159 & $* * *$ \\
\hline & $(0.003)$ & & $(0.003)$ & & $(0.003)$ & \\
\hline \multirow[t]{2}{*}{ Reinsurance } & -0.0091 & $* *$ & -0.0068 & & -0.0105 & $*$ \\
\hline & $(0.004)$ & & $(0.005)$ & & $(0.006)$ & \\
\hline \multirow[t]{2}{*}{ Product Herf } & 0.0143 & $* *$ & 0.0109 & & 0.0053 & \\
\hline & $(0.007)$ & & $(0.008)$ & & $(0.009)$ & \\
\hline \multirow[t]{2}{*}{ Foreign } & 0.0033 & & 0.0048 & $*$ & 0.0023 & \\
\hline & $(0.002)$ & & $(0.003)$ & & $(0.003)$ & \\
\hline \multirow[t]{2}{*}{ Mutual } & -0.0110 & $* * *$ & -0.0120 & $* * *$ & -0.0154 & $* * *$ \\
\hline & $(0.003)$ & & $(0.003)$ & & $(0.003)$ & \\
\hline \multirow[t]{2}{*}{ Group } & 0.0075 & $* * *$ & 0.0096 & $* * *$ & 0.0146 & $* * *$ \\
\hline & $(0.003)$ & & $(0.003)$ & & $(0.003)$ & \\
\hline \multirow[t]{2}{*}{ Premiums/Surplus } & 0.0051 & $* * *$ & 0.0051 & $* * *$ & 0.0066 & $* * *$ \\
\hline & $(0.001)$ & & $(0.001)$ & & $(0.002)$ & \\
\hline \multirow[t]{2}{*}{$\mathrm{PTROA}_{t}$} & 0.6996 & $* * *$ & 0.6633 & $* * *$ & 0.5729 & $* * *$ \\
\hline & $(0.040)$ & & $(0.041)$ & & $(0.055)$ & \\
\hline Year FE & Yes & & Yes & & Yes & \\
\hline $\mathrm{R}^{2}$ & $70.99 \%$ & & $68.85 \%$ & & $62.06 \%$ & \\
\hline F-Stat & 134.81 & & 136.82 & & 101.26 & \\
\hline Observations & 2,215 & & 1,968 & & 1,744 & \\
\hline
\end{tabular}




\section{Table 8}

Determinants of Admitted DTAs: Insurers versus Banks

This table reports results from an OLS regression of DTA (equal to admitted deferred tax assets scaled by total deferred tax assets for insurance companies and deferred tax assets included in Tier 1 capital scaled by total deferred tax assets for bank holding companies) on SSAP10R and SSAP101 (binary variables equal to one during years when SSAP 10R and SSAP 101 were enforced, respectively, and zero otherwise) and Insurer (a binary variable equal to one for insurance companies and zero for bank holding companies). See Appendix A for additional variable definitions. $* * *, * * *$ indicate statistical significance at the $0.10,0.05$, and 0.01 levels, respectively (two-tailed tests). Standard errors are clustered by firm and are presented in parentheses under coefficient estimates. We winsorize all continuous explanatory variables at one and 99 percent.

\begin{tabular}{lc}
\hline DV: Admitted DTAs (Tier 1 DTAs)/Total DTAs \\
\cline { 2 - 2 } SSAP101 & $-0.0556 * * *$ \\
SSAP10R & $(0.018)$ \\
& $-0.3742 * * *$ \\
Insurer & $(0.027)$ \\
& -0.0137 \\
SSAP101*Insurer & $(0.018)$ \\
& $0.1352 * * *$ \\
SSAP10R*Insurer & $(0.031)$ \\
& $0.1380 * * *$ \\
Liabilities/Surplus & $(0.028)$ \\
& 0.0012 \\
PTROA & $(0.002)$ \\
& $0.5359 * *$ \\
Size & $(0.209)$ \\
& 0.0073 \\
R-Stat & $(0.007)$ \\
Observations & $11.14 \%$ \\
& 39.99 \\
\end{tabular}




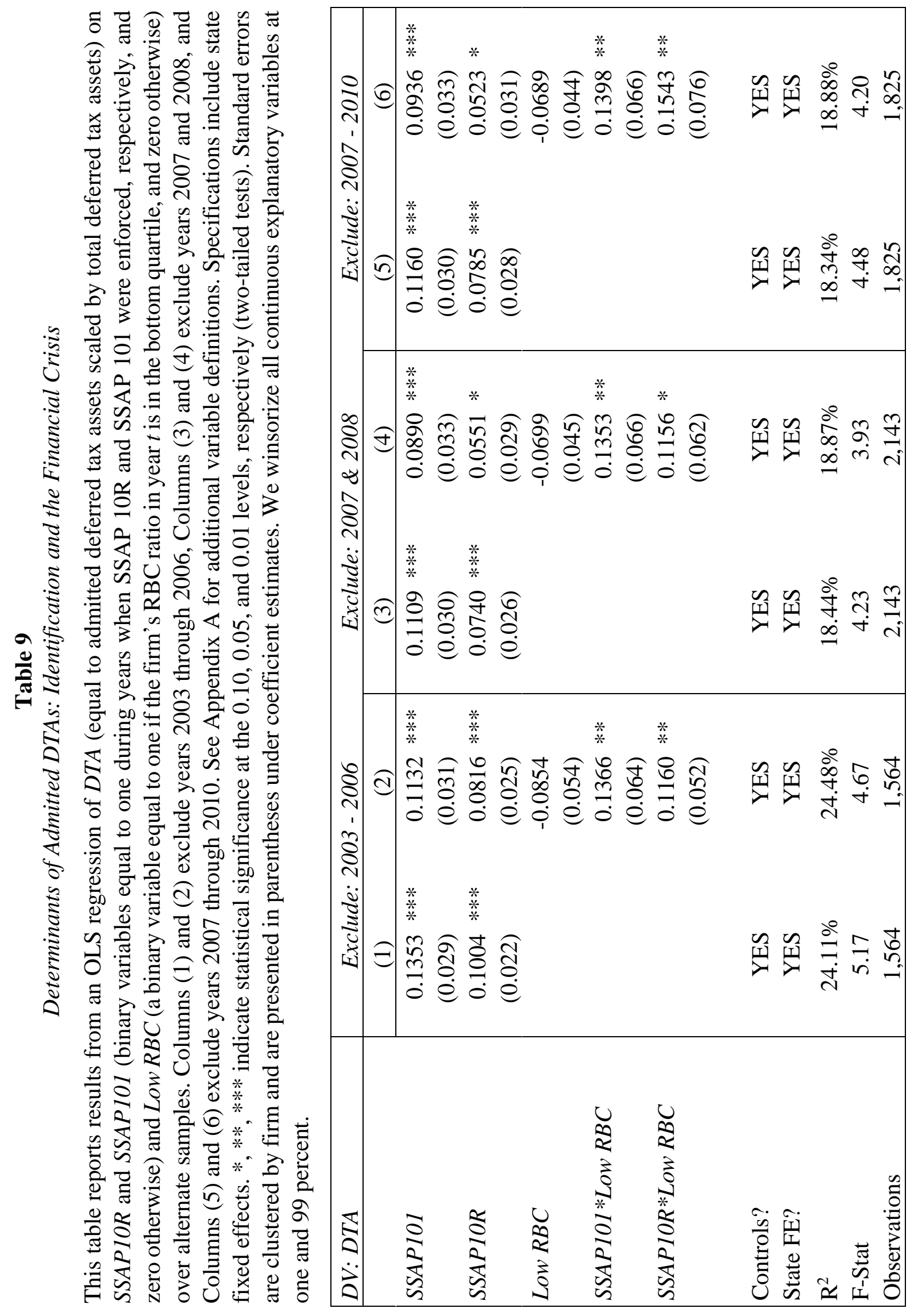

$\stackrel{๑}{7}$ 